\title{
IGF signaling pathway as a selective target of familial breast cancer therapy
}

Vivek Shukla $^{1 \#}$, Xavier Coumoul ${ }^{2 \#}$, Athanassios Vassilopoulos ${ }^{1 \#}$, Chu-Xia Deng ${ }^{1 *}$

${ }^{1}$ Genetics of Development and Disease Branch, 10/9N105, Diabetes Branch, National Institute of Diabetes, Digestive and Kidney Diseases, National Institutes of Health, Bethesda, Maryland, MD 20892, USA ${ }^{2}$ INSERM UMR-S 747, Université Paris Descartes, Centre universitaire des Saints-Pères, 45 rue des Saints Pères, 75006 Paris, France.

\#These authors contribute equally

*To whom correspondence should be addressed

Tel: (301) 402-7225; Fax: (301) 480-1135

Email: chuxiad@bdg10.niddk.nih.gov 


\begin{abstract}
Hereditary breast cancers affect women who have an increased risk of developing tumors because of a familial history. In most cases, they can be attributed to mutations in the breast cancer associated gene 1 and 2 (BRCA1 and BRCA2). Recent studies have demonstrated a link between the insulin-like growth factor (IGF) signaling pathway and familial breast cancer incidence. IGF and IGF receptors represent a family of biological growth factors and transducers, which have been involved in both physiological and pathological processes. It has been shown that BRCA1 regulates expression of several members of the IGF family. Here, we will examine our understanding of the functions of IGF/IGF-receptor signaling, the development of new inhibitors of this pathway and the related mechanisms of familial breast cancer formation.
\end{abstract}




\section{Introduction}

Breast cancer is the most common carcinoma in women with more than 1 million cases each year [1-3]. The incidence of breast cancer is increasing especially in young women. Familial susceptibility to breast tumor development represents about 5-10\% of all cancer cases [4-6]. A familial history contributes to a higher risk to develop the disease; for example, a firstdegree relative with breast cancer contributes to a risk ratio of 2.4. This increases with a lower age-incidence (under 50 years) and with the number of disease-prone relatives (with a risk ratio between 2.4 and 3.9). Familial breast cancer can be due to polymorphic combination of low penetrance genes conferring high tumor susceptibility or to mutations of higher penetrance genes. Linkage analysis studies have allowed the discovery of the first hereditary breast cancer genes named breast cancer associated gene 1 and 2 (BRCA1 and 2) [2-7-8]. Recent genome-wide association studies have identified four novel breast cancer susceptibility loci (FGFR2, TNRC9, MAP3K1 and LSP1) that might be responsible for a mildly increased risk [9-11].

Approximately $40 \%$ of familial breast cancers are caused by mutations of BRCA1 and carriers have a 50-80\% risk of developing breast cancer by the age of 70 [12-15]. BRCA1 interacts with numerous proteins that play important functions in many biological processes [16-17]. Several studies suggest a potential link between BRCA1-regulated gene expression and the Insulin-like Growth Factor (IGF) System. IGF proteins and their receptors (IGF-R) belong to well-described membrane tyrosine kinase signaling. This system is not only implicated in regulation of physiological processes but has also been linked to breast cancer formation and metastasis [18]. Pre-clinical and clinical studies (Phases I \& II) targeting the IGF pathway have been implemented in therapeutic actions specifically throughout the use of monoclonal antibodies [19]. Several studies have shown that BRCA1 deficiency in mice or human cell lines in culture leads to increased expression of several members of the IGF 
pathway resulting in carcinogenic effects. Targeting these proteins in cultured BRCA1deficient cancer cells also results in impairment of cell growth and survival. These observations suggest that preventive and therapeutic strategies used for BRCA1 mutation carriers might also benefit of IGF-targeting actions and improvement of pre-existing strategies for breast cancer families. The aim of this study is to present i) the IGF system (including growth factors, membrane receptors and downstream effectors) and its cellular or physiological functions, ii) the general aspect of familial breast and ovarian cancer epidemiology and present therapies including early organ monitoring, chemoprevention, invalidating prophylactic surgeries, and iii) the direct links between cancer development (including hereditary breast tumor) and the IGF system suggesting potential new preventive actions and therapies for BRCA1 carriers.

\section{The IGF system}

\section{Presentation of IGF, IGF-R \& IGFBP}

Since the description of the "somatomedin hypothesis" [20], which proposed the role of insulin-like growth factor-I (IGF-I) as a mediator of the action of growth hormone, many studies have tried to unravel the role of the IGF system on several tissues and different cell types. Its complexity is mainly due to the fact that it includes two soluble ligands, three cell surface receptors and six circulating binding proteins (Fig. 1). IGF-I is a small polypeptide of 7,5 Kd and a member of one family of structurally related peptides that also includes insulinlike growth factor II (IGF-II). Actually, the primary sequences of human IGF-I and IGF-II are $62 \%$ identical, whereas these two proteins share about $50 \%$ amino acid sequence homology with proinsulin [21]. The two polypeptides are classified into four domains (B, C, A and D) and their three dimensional structures are known [22-23]. Three alpha helices are the major secondary structural elements of IGF-I, IGF-II and insulin located in both the A and B 
domains. Despite the significant structural similarity between these peptide hormones, they have distinct and different functions. In mammals, insulin is implicated in metabolic regulation in muscle, adipose tissue and liver. On the other hand and besides the insulin-like metabolic action, IGFs are considered to act mainly as growth promoting factors. This role has been proven in animal models where mice with a targeted disruption of the IGF-I or IGFII gene are born at $60 \%$ birth weight compared to wild-type littermates [24-25], implying that both are necessary for normal growth. However, IGF-II is unable to compensate for the loss of IGF-I activity in patients with an IGF-I deficiency leading to severe growth and mental retardation [26]. Although IGF-II is thought to be required for embryonic development and IGF-I is essential later in life [27], experiments in knockout mice have shown that both are necessary for normal embryonic development [28]. The biological actions of the IGF ligands depend on their specific interaction with cell surface receptors. Given that these interactions result in activation of unique signaling pathways, the study of the ligand-receptor interactions is crucial in understanding the role of these peptides in inducing biological outcomes.

The IGFs bind with high affinity to two cells surface receptors, the IGF-I receptor (IGF-IR), which has a high degree of homology to the insulin receptor, and the IGF-II receptor (also called the cation-independent mannose-6-phosphate receptor, IGF-IIR/M6P). Due to the significant similarity between the IGF-IR and the insulin receptor, there is a crosstalk between the two systems [29]. IGF-IR and insulin receptor are both synthesized as precursors that finally will be processed to form the mature receptors. Both are transmembrane tyrosine kinase receptors composed of two $\alpha$ subunits that contain the extracellular hormone binding domain and two $\beta$ subunits that contain intracellular tyrosine kinase catalytic activity domains linked together with disulphide bonds [19]. After ligand binding to the extracellular region, the conformational structure of the receptor changes leading to tyrosine phosphorylation of the intracellular $\beta$ subunits with subsequent increase in 
the intrinsic kinase activity of the receptor [30-31]. In contrast, IGF-IIR has a different structure compared to the other two receptors. It consists of 15 repeating extracellular domains, a transmembrane domain of 23 amino acids and a 163 amino acid intracellular region. The different structure affects the function of the receptor since IGF-IIR has no intrinsic signaling transduction capability [32-33] and serves as a scavenger for IGF-II. Each IGF ligand binds preferentially to its specific receptor. For example, the type I receptor binds IGF-I with the highest affinity but also binds IGF-II and insulin with approximately 10- and 100-fold lower affinity, respectively. IGFs may interact with insulin receptor and promote signal transduction, although with lower affinity than insulin. Interaction between IGF-IR and its ligands leads to the activation of the receptor, which mediates many physiological responses such as growth regulation, cell proliferation, differentiation and migration (Fig. 1). Given the close homology of the IR and the IGF-IR, heterodimers composed of one IR $\alpha$ and $\beta$ subunit complex and one IGF-IR $\alpha$ and $\beta$ subunit complex are formed in cells expressing both receptors [34-35]. In contrast, IGF-IIR exhibits a higher specificity in terms of binding ligands as it binds mainly IGF-II with high affinity, whereas interaction with IGF-I is very low and it does not bind insulin. As mentioned before, this receptor lacks the ability to trigger any signaling within the cell and primarily acts to sequester IGF-II from any possible receptor activating interaction and to internalize and degrade IGF-II (reviewed in [36-37]).

Several factors control the synthesis of IGFs. Growth hormone regulates positively the secretion of IGF-I both in the connective tissue cell types affecting somatic growth [25] and in the liver determining plasma concentrations of the hormone [38]. Apart from this direct regulation, the bioavailability of IGFs in blood is also indirectly regulated either positively or negatively by the levels of a family of proteins called the IGF binding proteins (IGFBPs). This family consists of six proteins (IGFBP-1 to -6), which under normal conditions bind at least $99 \%$ of the IGFs in the circulation [39]. These are small proteins ( 30 
$\mathrm{Kd}$ ) where the cysteine-rich $\mathrm{N}$ and $\mathrm{C}$ terminal domains are connected by a flexible linker region. IGFBP-3 is the most abundant IGFBP in the blood playing an important role in stabilizing IGF-I. After binding both the hormone and acid labile subunit (ALS), the complex has a half-life of 16 hours, whereas the half-life of free IGF-I is less than 15 minutes [40]. The second most abundant protein is IGFBP-2 followed by IGFBP-1, 4, 5 and -6 , each one exhibiting different IGF-binding affinities. In tissues, their role is dual as they can both sequester IGFs from IGF-Rs blocking their action and release IGFs, which now can interact with their receptors, activating the cascade of signal transduction within the cell. The IGF binding affinity for IGFBPs is greater than that for IGF-Rs. Thus, IGFBPs can competitively regulate IGF binding and signaling. However, proteolysis of IGFBPs [41], binding of IGFBPs to the extracellular matrix [42] or phosphorylation-mediated change of the affinity for IGFs [43] may induce release of IGFs. Although it seems that IGFBPs may also have IGF-independent actions [44], they have an indispensable role in regulating IGF-dependent signal transduction by affecting the interaction between IGFs and IGF-Rs.

\section{Signal transduction by the IGF-IR}

As mentioned above, the IGF signal transduction pathway depends on the activation of the IGF-IR. Binding of IGF-I causes the activation of the tyrosine kinase, leading to autophosphorylation of the intrinsic tyrosines and tyrosine phosphorylation of multiple cytoplasmic substrates. More specifically, mutational studies [45-46] have revealed that the phosphorylation of three conserved tyrosine residues, 1131, 1135 and 1136, within the activation loop of the catalytic domain is necessary for the phosphorylation of a number of other tyrosines and serines, such as tyrosines 1250, 1251 and 1316 and serines 1280-1283, in the cytoplasmic tail of the receptor and subsequent recruitment of adaptor molecules. After this initial activation of the receptor, tyrosine residues provide docking sites for the insulin 
receptor substrate (IRS)-1/4 and the Shc (Src homology collagen) proteins (p46/p52/p66), which serve as signaling nodes for distinct intracellular pathways. The two best-characterized pathways triggered by the activation of the receptor are the PI3-K (phosphatidylinositol 3Kinase) and the classical ERK1/2 (extracellular signal-related kinase) MAPK (mitogen activated protein kinase) cascade. Phosphorylated IRSs bind the regulatory subunit (p85) of PI3-K via its SH2 domain and p85 binds the catalytic subunit of PI3-K via its SH3 domain. Subsequently, the PI3-K generated phospholipids facilitate the recruitment of other PH domain-containing proteins including the serine/threonine kinase Akt/PKB (protein kinase B). Other kinases such as p70rsk and protein kinase $\mathrm{C}$ may also serve as targets for downstream signaling of PI3-K. The result of PI3-K-mediated signaling affects many biological responses of IGFs especially those related to protein synthesis, mitogenesis, inhibition of apoptosis, and gene transcription regulation. Alternatively, both IRSs and Shc (Src-homology collagen) can bind to the activated receptor through their SH2 domains. Subsequent phosphorylation on tyrosine residues by the receptor leads to the recruitment of both Grb2 (growth factor receptor-bound protein) and the guanine nucleotide exchange factor Sos (son of sevenless). The resulting loading of GTP onto the small G protein Ras is the first step in the activation of the Ras/Raf/MAP kinase pathway, which is implicated mainly in the cell proliferative response to growth factors [47-48]. However, it seems that there is also a cross-talk between these two pathways since Akt can phosphorylate Raf protein kinase on Ser259. This phosphorylation results in blocking of the ERK signal pathway due to the interaction of Raf with 14-3-3 proteins [49].

Besides the above-mentioned pathways, IGF-IR is also coupled to the stimulation of Janus Kinases (JAK) 1 and 2, which then can phosphorylate/activate the signal transducers and activators of transcription (STAT) proteins mediating the transforming activity of the receptor [50]. Other proteins involved in downstream signaling of IGF-IR are cytoplasmic 
proteins such as the proto-oncogene c-CRK, which enhances IGF-I signaling [51], the adaptor protein Grb10 [52], phosphatases like Syp, PTP-1B and PP-2A [53-54], as well as G protein-coupled receptors [55].

\section{Involvement of the IGF system in human malignancy (transformation, tumor} growth, metastasis)

The IGF system plays a critical role in regulating many different physiological responses due to both autocrine and paracrine actions. However, it has been implicated in various malignancies, including colorectal, pancreatic, ovarian, melanoma, glioblastoma, prostate and breast cancer. Several studies using both in vitro and in vivo models in combination with epidemiological studies have proven the interplay between the IGF system and the malignant phenotype.

Cell culture studies have clearly established that IGFs regulate some specific characteristics like cell-cycle progression and proliferation as well as inhibition of apoptosis, which is activated in order to eliminate the transformed cells. As far as the cell-cycle progression, IGFs increase cyclin D1 expression which is the main regulator of cyclindependent kinase 4 (CDK 4), through specific PI3-K activation [56-59], [60-63]. Also, IGF-I activates p70 S6K, leading to phosphorylation of the S6 ribosomal protein and increased ribosomal pool necessary for entry into the cell cycle [64]. Alternatively, IGFs can downregulate expression of some inhibitors of CDKs (CDKIs), including p27 [65-66]. Furthermore, the IGF axis also affects the $\mathrm{G} 2$ to $M$ transition. Although, much less experimental data has been published in this field compared to its role in G1 phase, it is known that IGF-IR-deficient cells either delay to enter G2 phase or accumulate in G2/M phase [67-68]. Since proliferative cells have to overcome the activation of apoptosis, it has been shown that IGF axis plays a role in this process as well [69]. Mainly through the 
activation of the PI3K/Akt pathway, IGF-I phosphorylates the anti-apoptotic protein Bcl-2 and the pro-apoptotic proteins Bad and/or procaspase-9. As a result, Bcl-2 is localized to mitochondria, whereas Bad binds to 14-3-3 leading to the cytoplasmic localization of the protein and inhibition of caspase-9. In contrast, in the absence of IGF-I signaling, unphosphorylated Bad translocates to the mitochondria. There, it induces release of the cytochrome $\mathrm{c}$ to the cytoplasm, subsequent activation of caspase- 9 and the fully activation of the intrinsic mitochondrial apoptotic pathway. The role of IGF signaling in apoptosis is not limited to this pathway and also affects the extrinsic apoptotic pathway through downregulation of FasL expression [70-71].

Other cellular properties reminiscent to malignant transformation have been linked to IGFs signaling including regulation of angiogenesis [72] [73-77], disruption of intracellular junctions [78] and degradation of extracellular matrix (ECM) or basement membrane by matrix metalloproteinases (MMPs) and the uPAR/uPA system [79-82]. In conclusion, the use of cell culture models clearly suggests an association between activation of the IGF signaling pathway and increased tumor survival and invasion [83-84].

On the other hand, in vivo and epidemiological studies on the role of the IGF system in breast cancer development have lead to conflicting issues. The effects described above allow transformed cells to proliferate and survive. These two phenomena are characteristics hallmarks of cancer cells. A long time ago, it was shown that IGF-IR expression correlates with fibroblast transformed phenotypes [85-87]. During the next years, the regulatory role of IGF axis in tumor growth was established as positive regulation of IGF signaling and was correlated with tumor development [88-90]. IGF-IRs are more frequently detectable in breast cancer cells compared to normal cells [91]; IGF-IR is overexpressed in primary breast carcinoma and activates pERK1/2 and pAKT in hormone receptor-positive breast cancer [92]. Other observations can make this story more complicated. In a study where IGF-IR 
expression was evaluated in formalin-fixed, paraffin-embedded tissue of 210 primary breast cancer patients, overexpression of the receptor was found only in $43.8 \%$ of tumors. Even more significant is the result that no correlation was found between the overexpression of IGF-IR and prognosis or other clinicopathological parameter [93]. In another study although IGF-IR expression was up-regulated in a large number of tested samples (with a frequency comprised between 39 and 47\%), only some of them have been correlated to a poor prognosis [92]. Moreover, Chong et al using a small number of samples $(n=20)$ did not find any difference in IGF-IR expression levels between adjacent breast cancer and non-neoplastic tissue [94].

These conflicts may be reconciled by recent studies showing that IGF signaling appears to be more important for breast tumorigenesis than IGF members' expression, especially IGF-IR. Similar IGF-IR protein levels do not necessarily correlate with equivalent phosphorylation status [95]. Animal models and analysis of human medulloblastoma samples also indicate that phosphorylated IGF-IR or downstream effectors (IRS1) levels might be a more reliable indicator of IGF axis contribution to tumor progression than the receptor levels [18]; for example, depending on the model, a high expression of IGF-IR may not be important if IRS1 is not expressed. Moreover, IGF-I levels might be more important than IGF-IR expression because it is directly responsible for triggering IGF signaling; indeed, overexpression of a particular form of IGF-I which has low-IGFBP and high-IGF-IR affinities in mice, increases the incidence of mammary adenocarcinoma [96-97]. In situ hybridization studies reported an increased IGF-I expression in stromal tissues surrounding tumor epithelial cells [98-100]. This is consistent with experiments indicating that mesenchymal cells provide an important paracrine source of IGF-I [18]. In accordance with these studies, higher circulating levels of either IGF-I or IGF-II in human subjects are associated with increased risk for breast carcinoma [101-103]. Epidemiological investigations 
suggest an association between cytosine-adenine dinucleotide (CA)n repeat polymorphisms of the IGF-I gene and IGF-I levels and further evidence indicates that genotype may influence breast cancer risk [104-105]. Indeed, Jernstrôm et al suggest in two independent studies, that lack of the IGF-I 19-repeat allele $(n=19)$ increases IGF-I levels, breast volume and possibly early-onset breast cancer risk after hormone exposure in young high-risk women [106-107]. This polymorphism has been suggested to serve as a marker for breast cancer risk in the general Jewish population [108]. In another study, Jernström et al show that normal BRCA1/2 carriers had higher IGFBP-3 levels than BRCA1/2-mutated carriers during cycle days 5-10 and 18-23. The lower levels of this IGF "inhibitor" in BRCA1/2 patients may account for a higher activity of IGF-I on their mammary epithelium [106]. On the other hand, decreased levels of IGF-I production has been correlated to tumor growth retardation in mice [109-110]. Reducing the levels of circulating IGF-I by deleting the gene in liver delays the onset of mammary tumors [111]. Another study of Carboni et al shows that expression of a constitutive form of IGF-IR triggers salivary and mammary adenocarcinomas by the age of 8 weeks [112]. Breast cancer cells selected for metastatic behavior in vivo also have increased IRS2 activation and signaling [113]. Same results were obtained in experiments using LCC6 cells (a metastatic variant of MDA-MB-435). In contrast to wild type cells, cells carrying a truncated IGF-IR receptor, which lacks the autophosphorylated residues in the carboxyl terminus, showed no metastases to the lungs after injection to nude mice [114].

In conclusion, these observations highlight the necessity for deeper investigation of the role of IGFs in tumor growth. The notion that they can affect almost any aspect of tumorigenesis, including angiogenesis and metastasis supports the major role of IGF system in cancer formation.

\section{Interactions between BRCA1 and the IGF system}


The BRCA1 gene is composed of 24 exons that encode a full length protein of 1863 amino acids in human, and 1812 amino acids in mice [8-115-116]. BRCA1 also encodes at least two smaller protein products: BRCA1-delta11 (also termed BRCA1-11b) that arises from in-frame splicing between exon 10 and exon 12, and BRCA1-IRIS [117-120]. The BRCA1-IRIS is a 1.399-residue polypeptide encoded by an uninterrupted open reading frame that extends from codon 1 of the known BRCA1 open reading frame to a termination point 34 triplets into intron 11 [117]. BRCA1 interacts in the cell with numerous proteins involved in various processes including DNA repair, transcription, cell cycle regulation, stress response, apoptosis and tumor suppressor functions [115-121].

Recent studies revealed that breast IGF-IR and IGF-IIR mRNA expression levels are generally higher in tissue from women with a family history of breast cancer [122]. The team led by Werner provides a molecular mechanism that might account for this phenomenon: Sp1 is a general transcription factor that is involved in regulation of gene expression including IGF-IR [123-124]. BRCA1 expression in Saos-2, MCF-7 and CHO cells (but not mutant BRCA1) blocks almost half of Sp1-induced transactivation of the IGF-IR promoter resulting in lower levels of the mRNA and protein [125-126]. BRCA1 does not bind directly the IGFIR promoter but prevents Sp1 binding through direct interaction with this protein [127]. They also show a significant elevation of IGF-IR levels in tumors from BRCA1 mutant carriers compared with non-carriers controls [128]. This phenomenon also depends on the genetic status of p53, another gene that has been implicated in hereditary breast cancer (Li-Fraumeni syndrome). Indeed, BRCA1 exerts its effect in both p53 positive and negative cell lines but is ineffective in cells that expressed a mutant of p53 [127-129] In this study, p53 has been reported to bind directly to BRCA1 [127-129].

Meanwhile, we have been studying potential interaction between IGF/IGF-IR and Brca1 in a mouse model carrying homozygous deletions of full length Brca1, and one 
heterozygous mutation of p53 $\left(\mathrm{BrCal}^{\Delta 11 / \Delta 11}, \mathrm{p5}^{+/-}\right)$which displays a higher frequency and latency of tumorigenesis [130-135]. We found that Brca1 deficiency leads to an $18 \%$ increase of IGF-I serum levels (Fig. 2A). Because the liver predominantly secretes IGF-I, we checked the corresponding mRNA and protein levels of this growth factor; we were able to show that both expressions increase. Microarrays experiments using total RNAs isolated from livers of Brcal $^{4_{11 / \Delta l 1}} \mathrm{p5}^{+/-}$and control mice allow us to detect alterations in several $I g f$ or insulinrelated genes, including Igf-IR and Irsl (Table 1). These changes were confirmed by realtime RT-PCR using total RNAs isolated from multiple tissues (Fig. 2B). To further study if modulation of Brcal protein levels could indeed affect expression of these members of the IGF pathway, we used the human UBR60 cell line, whose BRCA1 expression levels can be controlled by a tetracycline-off system [136]. Induction of BRCA1 decreases both IGF-IR and IRS1 expression and subsequently reduces AKT phosphorylation, a downstream event in the IGF cascade. Conversely, decreased expression of BRCA1 in these cells using RNA interference leads to increase IGF-IR and IRS-1 levels (Fig. 2C, D). Another group performed immunohistochemistry experiments on cancer samples from BRCA1/2 mutation carriers and unrelated patients with no familial history; they show that both IGF-I and IGF-IR protein levels are up regulated in BRCA1/2-deficient samples. They also utilized RNA interference on primary human mammary cells to show that BRCA1 levels are inversely correlated to IGF-I expression (Hudelist G, Wagner T, 2007, Endocrine Related Cancer).

We provided additional experiments to decipher the regulatory mechanism for Irs-1 regulation; Chromatin immunoprecipitation (ChIP) assay indicates that BRCA1 binds to the IRS-1 promoter sequence in both presence and absence of tetracycline (Fig. 2E). However, the intensity of the band from was significantly stronger upon BRCA1 induction. The ChIP assay also indicated that when BRCA1 levels are low, the IRS-1 promoter is associated with transcriptionally favorable histone modifications (high levels of H3-Acetylated K9 
(H3AcK9), H3Me3K4, Histone 4 (H4) H4Me3K20, and H4AcK16, and low levels of H3Me3K9) (Fig. 2E). On the other hand, high levels of BRCA1 correlate with transcriptionally repressive histone modifications (Fig. 2E). These results provide evidence that increased expression of IRS-1 in BRCA1 deficient systems is directly due to BRCA1 recruitment at the promoter level and associated transcriptional down-regulation [136].

The influence of IGF-I on tumorigenesis prompted us to examine its levels in mammary tumors. We showed that mammary tumors significantly exhibited increased $I g f-1, I g f-I R$, and Irs-1 mRNA levels than normal tissues (Fig. 3A). Because these tumors were also deficient in p53, this suggests that activation of IGF signaling upon Brcal deficiency occurs, for this model, in a p53-independent manner [136].

IGF signaling has been associated with cell survival and proliferation. To establish a causal relationship between the increased IGF signaling and cancer cell proliferation, we suppressed Irs-1 with one shRNA in three BRCA1-deficient tumor cells (i.e. 69, 525, 780) [17]. We found that down regulation of IRS-1 levels was accompanied by a dramatic reduction in cell growth three days after transfection (Fig. 3C). Interestingly, we observed that the two main pathways downstream of IRS-1 were also down-regulated with a dramatic reduction of AKT and MAPK phosphorylation levels (Fig 3B). Meanwhile, significant inhibitory effects were detected in all three Brcal mutant cells lines but not in a Brcal wild type control cell line (Fig. 3D-G). In one cell line, suppression of Irs-1 expression led to a complete inhibition of cell growth [136].

Of note, a recent study revealed that IGF-I and Sp1, which have been involved in IGFIR expression, also positively regulate BRCA1 transcription [128]. These data suggest a potential negative regulatory feedback loop that limits IGF signaling in cells expressing normal BRCA1. 
BRCA1 might also regulate IGF-related members through inhibition of estrogen receptor- $\alpha$ (ER- $\alpha)$ signaling, which has been positively implicated in regulation of several IGF members (REF). Indeed, Rosen et al have shown that transient transfection of wild-type BRCA1 into the mammary cell line, MCF-7, inhibits ER- $\alpha$ signaling through direct in vitro and in vivo binding. BRCA1 blocks the transcriptional activation function AF-2 of ER- $\alpha$ and as a consequence, the activation of estrogen-responsive enhancer elements and the expression of two endogenous estrogen-regulated gene products in human breast cancer cells (pS2 and cathepsin D). Interestingly, several truncated BRCA1 proteins containing the amino-terminal ER-alpha binding region blocked the ability of the full-length BRCA1 protein to inhibit ERalpha activity (Fan S, 1999 and 2001, Science and Oncogene). However, recent investigations by Hosey et al (Hosey et al, 2007, JNCI) suggest that wild-type BRCA1 expression has been correlated to ER production. Both BRCA1 overexpression and siRNA-downregulation have been used for this study. Further investigations are needed to precise this potential indirect effect of BRCA1 on IGF-related members regulation.

\section{Targeting the IGF pathway to prevent the development of familial breast cancer}

Few preventive actions can be undergone to inhibit IGF-related tumorigenic effects; for example, accumulating epidemiological evidences show that insulin resistance in overweight people might be important to explain the higher incidence of cancer in this population. The hypothesis is that chronic hyperinsulinemia is associated with decreased concentrations of both IGFBP-1 and IGFBP-2, leading to increased availability of IGF-I [137]. Reduction of IGF-I levels can be accomplished through a calorie-restricted diet [138-139] and could represent a potential way to prevent development of tumors (including tumors of the breast) in high-risk families especially for overweight people. Reduction of IGF-I levels might also be performed in vivo using GHRH, somatostatin and GH antagonists; GHRH antagonist, JV- 
$1-36$, has been shown to inhibit in vivo breast cancer growth probably through reduction of IGF signaling [140]. Moreover, pegvisomant, a polyethylene glycol derivative GH antagonist, is also efficient in vivo against breast cancer cell lines [141-142]. Restoration of IGF-I serum levels in a mouse model of prostate carcinogenesis, which has been caloricrestricted (and then with lower serum levels of IGF-I), increased the stage of the cancers and cell proliferation in hyperplastic foci [138]. Alternatively, IGFBP proteins could be used to inhibit IGF-I serum levels considering their high affinity properties [143]; however, this alternative might be difficult to be tested in clinical trials considering the extremely short half-life of these proteins. Such strategies could be envisaged upon stabilization of IGFBPs in vivo, which is still a subject of research. Another concern is the consequence of long-term down-regulation of IGF-I serum levels which might be difficult to undergo considering the benefits of maintaining this growth factor levels for elderly adults (neuro-protection, brain plasticity, muscle mass maintenance) [144-145]. On the other hand, numerous strategies have been undergone to target directly the IGF pathway during the process of tumorigenesis.

\section{Monoclonal antibodies}

Monoclonal antibodies are among the most widely used tools to target IGF-IR or IGFI/II. Those studies used cell lines or mice models to show, in most cases, a clear reduction of breast tumor growth or size and/or IGF-IR membrane expression [146]; depending on the study, the antibodies (injected for several weeks to immunodeficient xenografted-mice) target the IGF-I binding domain preventing the action of the growth factor like downstream phosphorylation events, or trigger IGF-IR internalization [147-153]. Li and colleagues showed that injection of their specific antibody (500 $\mu \mathrm{g} /$ mouse, twice a week) significantly suppressed MCF-7 tumor growth in immunodeficient mice [150]. The mechanism might be a little bit more complex than a simple inhibitory interaction. Indeed, Sachdev et al showed that 
the antibody stimulates short and transient biochemical activation of IGF-IR and subsequent receptor down-regulation, making MCF-7 cells refractory to IGF-I exposure [152]. In two other independent studies using two different antibodies, the authors enhanced chemotherapeutics tamoxifen-based treatment, suggesting an overall synergistic benefit to combine those different strategies [148-153]. The same strategy has been successfully applied by another group using a different high-affinity IGF-IR antibody; in this case, they were able to block IGF-I binding, IGF-IR internalization on tumor cells and significant growth reduction (and induce IGF-IR internalization on tumor cells and significant growth reduction) of xenografted tumors in mice [147]. In two other papers, the use of a bi-specific antibody targeting both IGF-I and EGF, or IGF-I and IGF-IR, was successful to prevent activation of downstream pathways including MAPK [154-155]. Interestingly, these strategies have been useful to decrease tumor size of other cancer types as well [156].

Several antibodies enter the clinical stages as a therapeutic alternative to reduce IGF-IR tumorigenic effects. AVE-1642 (Immunogen Inc./Sanofi Aventis), a humanized form of the antibody developed by Maloney et al [151] has entered phase I clinical trials (test of the antibody on healthy voluntary subjects) (http://www.immunogen.com). The A12 antibody developed by Burtrum [147] has also been used in phase I and phase II studies. For the Phase-II clinical trail (test on patients to evaluate the efficacy, safety and pharmacology of the agents), 40 to 72 patients are expected to be enrolled to test the combination of A12 and cetuximab (an antibody which targets EGF-R) administered every two weeks. Four clinical trials are on their way for another IGF-IR antibody (CP-751871) [157] developed by Pfizer Global Research Development including two phase II studies (http://www.cancer.gov/search). One of them is testing the efficacy of CP-751871 combined with exemestane (an aromatase inhibitor used to treat advanced breast cancer and to prevent recurrent breast cancer in postmenopausal women who have already been treated with 
tamoxifen) in the treatment of postmenopausal patients with hormone positive advanced breast cancer. The Pierre Fabre/Merck company and Schering-Plough Research Institute have also developed their specific antibodies, respectively 19D12 and A2CHM (derived respectively from the studies of Wang et al and Bohula et al [158-159] (information about these preclinical trials can be found at the website http://www.cipf.com/public/cipf/html/en/our_projects/project.php).

Alternatively, IGF-I antibodies could be used to neutralize both IGF-I and IGF-II receptor-binding (steric occupancy). Several studies have reported the use of such antibody to inhibit the growth and migration properties of culture cell lines [160-161]; however, no such antibodies have ever been used to our knowledge for clinical trials yet.

\section{IGF-IR tyrosine kinase inhibitors}

Competitive inhibitors of the ATP binding domain of the IGF-IR have been developed with a specific challenge because in most cases they bind to both IGF-IR and IR (IGF-IR and IR share $84 \%$ sequence homology in their active sites). Most preliminary tests have been performed in the same animal models as the ones used for antibodies trials. One specific study on breast cancer shows an inhibition of tumor growth [162] while studies on other cancer types also demonstrate their efficiency to reduce tumor size and/or invasiveness [156]. Considering their anticipated actions on insulin effects and blood glucose levels (while blocking insulin metabolic effects on the whole organism might be deleterious, their action on the insulin receptor expressed by the tumor cells might be beneficial) [163], none of them has entered clinical trials and they are still at the preclinical stage (including the tyrphostins AG1024, AG1034 from Clinisciences [164-165]) and BMS-55417/536924 from BristolMyers Squibb [166]). However, binding of the insulin receptor has only been tested for some of them and this remains to be validated for all developed molecules before ruling out the 
potential use of those molecules to treat breast cancer. For example, other tyrphostins including the EGFR kinase inhibitor AG1571 has been used in clinical trials since early 1997. More specific molecules have been developed to target the IGF-IR receptor: pyrrolo[2,3d]pyrimidine derivatives (NVP-AEW541/ADW742) exhibit a higher specificity (16-fold for AEW541) for IGF-IR in cellular assays but still display an inhibitory effect on the insulin receptor due to their ATP competitive ligand activity and the homology between both kinase domains [167-168]. Specifically, dose-response experiments will be needed to clearly specify the dose-action window of those inhibitors on both IGF-IR and insulin receptors. Recently, cyclolignans, a class of molecules derived from plants, do not compete for the ATP binding site but inhibit autophosphorylation of the receptor [169-170]. All of them are still in preclinical trials. Finally, INSM-18 is an orally available small molecule that inhibits IGF-I and HER2 tyrosine kinases. In two single-doses Phase I clinical studies, the drug was safe and well-tolerated. Additionally, a Phase I-II dose escalation clinical study designed to define the maximum tolerated dose of INSM-18 in patients with relapsed prostate cancer has been completed at the University of California, San Francisco. This study consisted of a 28-day treatment period at each dose level to investigate the effect of INSM-18 on levels of prostate specific antigen (PSA). An analysis of the data collected from the study is currently being conducted, and the results will be used to design further Phase II clinical studies (http://investor.insmed.com)

\section{Small interfering and hairpin RNA (siRNA, shRNA).}

Numerous studies on cell lines have been published on this subject; they demonstrate a convincing effect of siRNA or shRNA in downloading IGF-IR expression levels and cell tumor growth [158-171-172]. As illustrated earlier, we have used the same approach with three different cancer cell lines, which do not express normal BRCA1 but a mutant form. 
Down-regulation of IGF-IR or IRS-1 mRNA and protein levels leads to cell growth inhibition and apoptosis. At the cell culture level, inhibition of IGF signaling by RNA interference or anti-sense strategies appears a suitable strategy to inhibit tumor growth [136]. However, in vivo siRNA is still not largely used and might not be suitable at the organism level. Nevertheless, the experiments based on BRCA1-expressing or non-expressing cell lines provide evidence that IGF signaling would be a suitable target for familial breast cancer therapies [136].

\section{Indirect strategies}

On the other hand, indirect ways could be envisioned to target IGF actions. Further studies will be needed to prove the activation of the MAPK pathway upon loss of BRCA1 in breast tumors (see above). Specific pharmacological antagonists targeting MAPK are already used in clinical trials, like BAY 43-9006 (Raf inhibitor), and PD184352, PD0325901 and ARRY142886 (MEK1/2 inhibitors) [173]. Another example is the synergy between IGF-I and HIF$1 \alpha$ to promote tumor growth [174-175]; novel anticancer agents have been developed to inhibit HIF- $1 \alpha$ and it could be imagined that they might exert an effect in familial breast cancers which show high expression of IGF-I [176-177]. Induction of matrix metalloproteases, MMP2 and MMP9, which promote cell invasion through degradation of the cellular environment, has also been directly linked to IGF signaling [80-178-179]. Despite early disappointing results on development of MMP inhibitors, new small synthetic molecules are in advanced clinical trials today with promising effects [180].

\section{Conclusion and Future Directions}

Mounting of evidence clearly established a stimulating role of IGF signaling in breast cancer initiation and progression. Recent studies have also implicated IGF signaling in familial 
breast cancer. IGF/IGF-R/IRS signaling interacts with at least two tumor suppressor genes, p53 and BRCA1, that are involved in familial breast cancer. Both p53 and BRCA1 can inhibit promoter activities of IGF-IR and/or IRS-1 in a dose dependent manner, and conversely absence of these genes results in activation of IGF signaling [125-127-129-136181-182]. Because majority BRCA1-mutant cancer also lost p53, it is conceivable that increased IGF/IGF-IR/IRS-1 signaling in BRCA1 mutant cancers is caused by the absence of p53. However, our data obtained from human UBR60 cells and a mouse Brca1 mammary tumor model indicated that the regulation of BRCA1 to IGF signaling could also be p53 independent. The activated IGF signaling proceed its effects through at least two main proliferative pathways: the Ras-MAPK-ERK pathway and the PI3K-AKT-mTOR pathways, which stimulate cell cycle progression through their downstream effectors, such as cyclin D1, AKT/mTOR, MET/ERK, cell cycle inhibitors and so on, eventually promoting cancer formation (Fig. 4).

Inhibition of IGF signaling presents a great hope in eradicating familial breast cancer formation. Several antibodies against IGF and IGF receptors have entered clinical trials. Promising data was also obtained by using specific inhibitors to target IGF and/or IGF receptor tyrosine kinase. A combination of effective antibodies and specific inhibitors should be considered to treat familial breast cancers, which showed increased levels of IGF, IGF-IR and/or IRS-1. This may lower doses of each product and generate less toxicity to enhance the efficiency and specificity of the treatment. In that case, this might be also included in preventive strategies, specifically in BRCA1 carriers.

Experimental systems using small interfering and hairpin RNA (siRNA, shRNA) to knockdown IGF-IR or IRS-1 mRNA and protein levels resulted in cell growth inhibition and apoptosis. However, difficulties in delivering the siRNA and/shRNA put a great challenge in their application to cancer patients. Future efforts should be directed to achieve safe and 
effective ways to administrate these agents. In this aspect, nanoparticles may serve as an effective vehicle for targeted delivery of the agents to cancers as demonstrated recently [183184].

Targeted therapeutic treatments could also be directed against MAPK/ERK and the AKT/mTOR pathways, both of which are activated at varying levels by IGF signaling. A MEK/ERK inhibitor, U0126, has been used in clinical trials for multiple different cancers. Our recent study also demonstrated that U0126 could effectively inhibit ERK phosphorylation a few hours after administration, and a prolonged treated completely reversed skeletal abnormalities caused by FGFR2/MEK/ERK activation [185-186]. Meanwhile rapamycin and its analogs, such as CCI-779, RAD001 and AP25373, which inhibit AKT/mTOR signaling, have also been used in the treatment of various types of mouse and human tumors. Future efforts should also be directed in testing these drugs either alone, and/or in a combination to developed powerful therapeutic regimes that kill familial breast cancers. 


\section{Figure legends}

Figure 1. Main signaling pathways involved in the IGF system. Upon release of IGFs from IGFBPs, IGF-I and IGF-II bind mainly to IGF-IR and IGF-IIR, respectively. Whereas the interaction of IGF-II induces internalization of the receptor and degradation of IGF-II, binding of IGF-I to its receptor activates signaling pathways implicated in significant biological responses such as proliferation and survival. The two best-characterized pathways triggered by the activation of the receptor are the PI3-K and the classical ERK1/2 MAPK cascade. Phosphorylated IRSs bind the regulatory subunit (p85) of PI3-K and p85 binds the catalytic subunit of PI3-K (p110). Subsequently, the PI3-K-generated $\mathrm{PIP}_{3}$ facilitates the recruitment and activation of the serine/threonine kinase Akt/PKB. Alternatively, upon activation of the receptor, IRSs may recruit Shc, Grb2 and Sos. These events are necessary for the loading of GTP onto the small G protein Ras, which is the first step in the activation of the Ras/Raf/MAP kinase pathway.

Figure 2. Increased expression of IGF axis members in Brca1 ${ }^{\Delta 11 / \Delta 11} \mathrm{p53}^{+/}$mice. (A) IGF-1 serum concentrations in 3-month old mice (ten animals for each group). (B) Real-time PCR analysis of Igf-I, Irs-1 and Igf-IR expression in the liver of wild type (WT) and Brca ${ }^{\Delta_{11 / \Delta 11}} \mathrm{p} 53^{+/}$mice. (C) Western blot using protein extracts from UBR60 cells [48h with (+) or without Tet (-)]. (D) RT-PCR analysis of BRCA1-expressing UBR60 cells (without tetracycline) $24 \mathrm{~h}$ after transfection with $B R C A 1$ siRNAs. (E) ChIP assay shows recruitment of BRCA1 to IRS-1 promoter and down-regulation of BRCA1 expression resulting in alteration of IRS-1 activity through epigenetic modifications. H3AcK9: histone H3Acetylated K9, H3Me3K4: histone H3-Trimethylated K4, H4Me3K20: histone H4Trimethylated K20, H4AcK16: histone H4-Acetylated K16, H3Me3K9: histone H3Trimethylated K9. 
Figure 3. Acute suppression of Irs-1 by RNAi inhibits mammary tumor cell growth. (A) Mammary tumors express high levels of IGF-I, IRS-1 and IGF-IR than normal mammary gland. (B) Western blot analysis of a Brca1 mutant mammary tumor cell line (69) at day 3 after mock and Irs-1 shRNA transfection. (C) 69 mammary tumor cells at days 0 and 3 after transfection with Irs-1 shRNA specifically. (D-G) Growth curves of three Brcal-deficient $(69,525,780)$ and one Brcal-expressing (Ras) mammary tumor cell lines using mouse Irs-1 shRNA.

Figure 4. An integrative model proposing a mechanism underlying BRCA1 dependent and independent activation of IGF-I signaling in tumor formation. 
Table 1. Microarrays analysis showing increased gene expression in the liver of $\mathrm{Brcal}^{\Delta 11 / \Delta_{11}} \mathrm{p53}^{+/-}$mice in comparison with the liver of $\mathrm{Brcal}^{\Delta 11 /+} \mathrm{p53}^{+/-}$mice.

\begin{tabular}{|l|c|c|}
\hline \multicolumn{1}{|c|}{ Gene name } & Symbol & $\Delta \Delta \Delta+$ \\
\hline Insulin induced gene 2 & Insig2 & 1.15 \\
\hline Insulin degrading enzyme & Ide & 1.23 \\
\hline Insulin-like growth factor binding protein 7 & Igfbp7 & 1.23 \\
\hline Insulin-like growth factor 1 & Igf-1 & 1.32 \\
\hline Insulin degrading enzyme & Ide & 1.41 \\
\hline Insulin-like growth factor binding protein, als & Igfals & 2.00 \\
\hline Insulin receptor substrate 1 & Irs1 & 2.00 \\
\hline Growth hormone receptor & Ghr & 3.77 \\
\hline Insulin-like growth factor binding protein 2 & Igfbp2 & 6.06 \\
\hline
\end{tabular}



Fig. 2
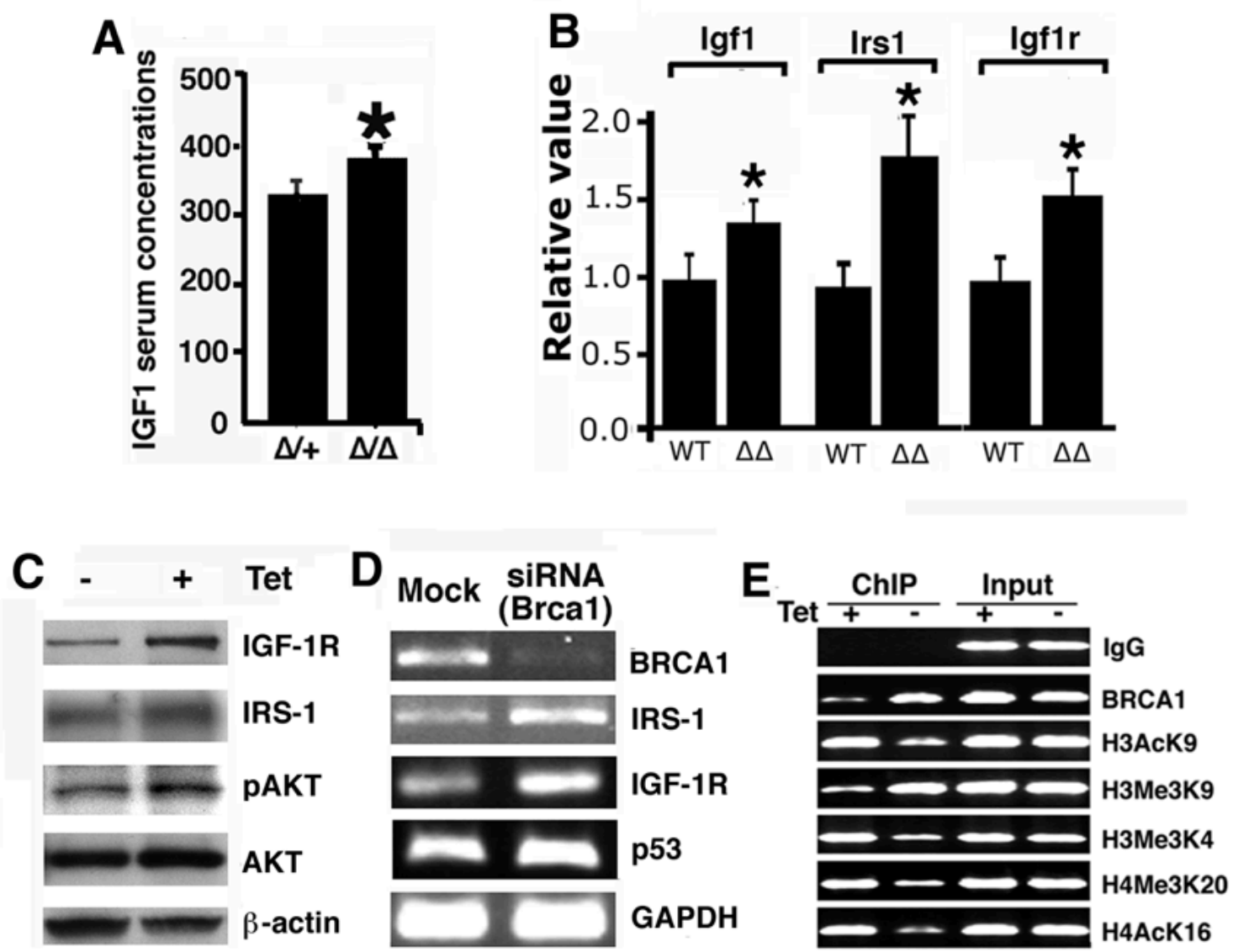
Fig. 3
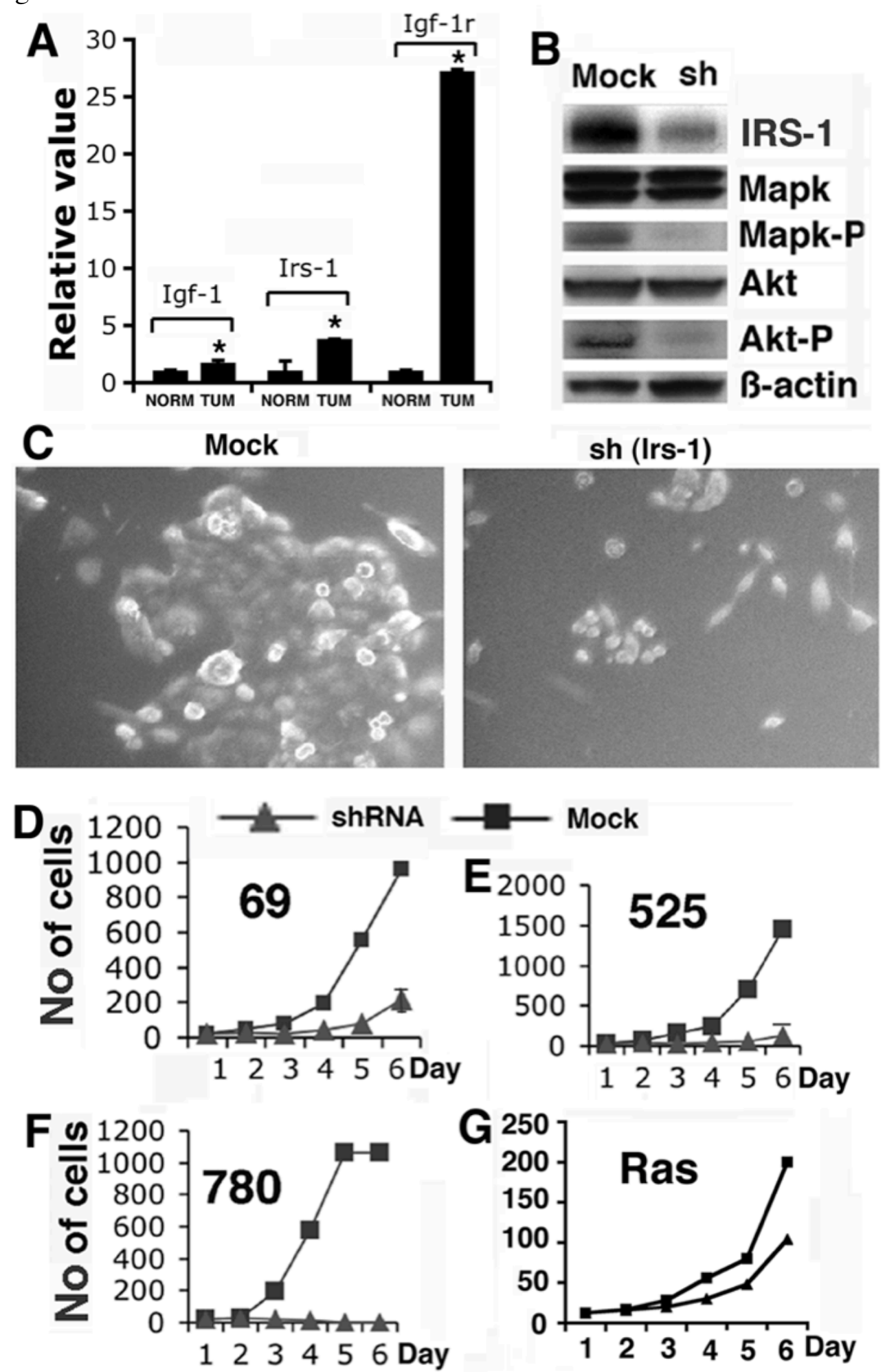
Fig. 4

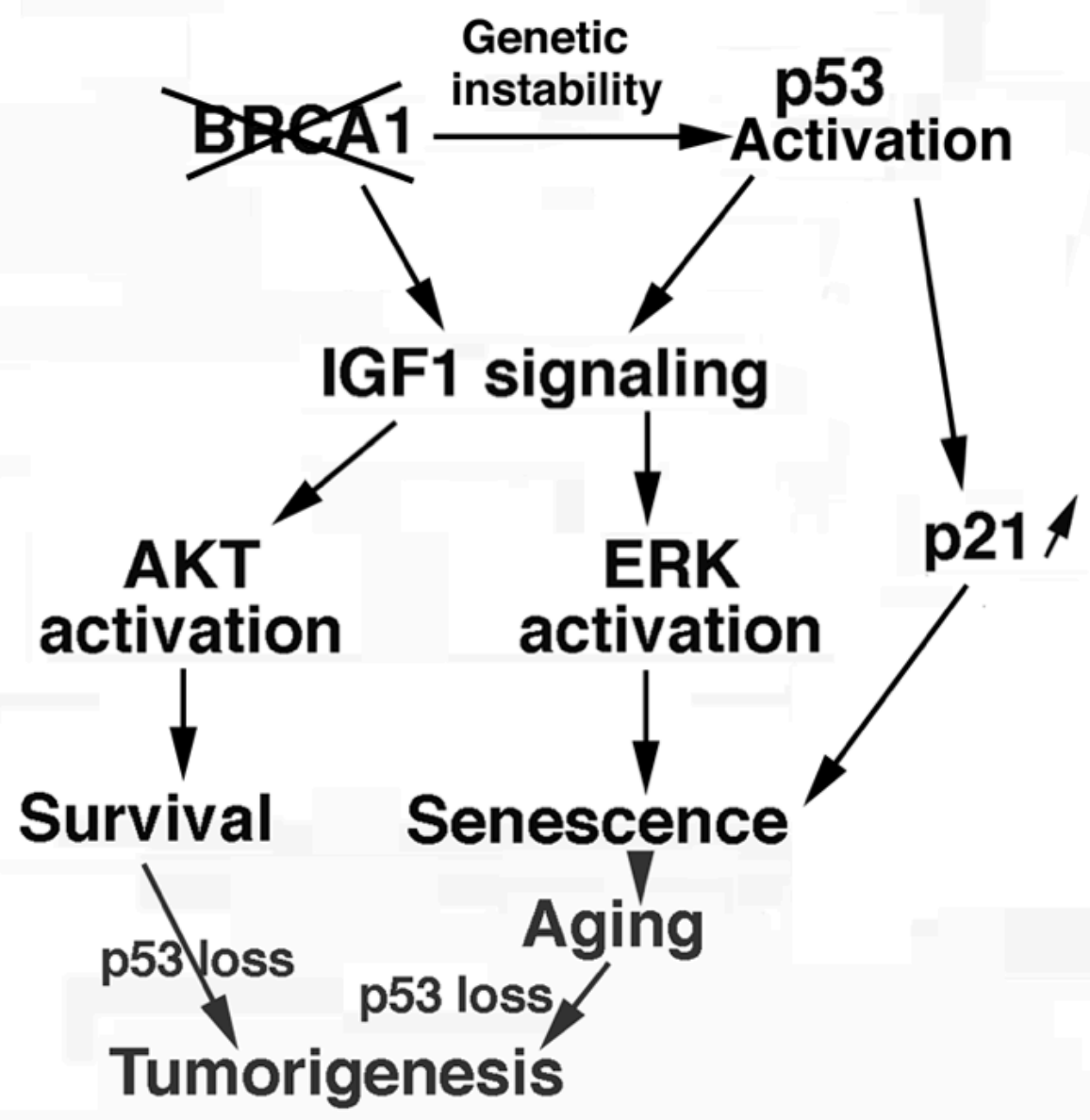




\section{Bibliography}

[1] Lynch, H.T., Silva, E., Snyder, C. and Lynch, J.F. (2007) Breast J,

[2] Roukos, D.H. and Briasoulis, E. (2007) Nat Clin Pract Oncol, 4, 578-590

[3] Silva, E., Gatalica, Z., Snyder, C., Vranic, S., Lynch, J.F. and Lynch, H.T. (2007) Breast $J$,

[4] Alberg, A.J., Lam, A.P. and Helzlsouer, K.J. (1999) Curr Opin Oncol, 11, 435-441

[5] Brody, L.C. and Biesecker, B.B. (1998) Medicine (Baltimore), 77, 208-226

[6] Eccles, D.M. and Pichert, G. (2005) Lancet Oncol, 6, 705-711

[7] Hall, J.M., Lee, M.K., Newman, B., Morrow, J.E., Anderson, L.A., Huey, B. and King, M.C. (1990) Science, 250, 1684-1689

[8] Miki, Y., Swensen, J., Shattuck-Eidens, D., Futreal, P.A., Harshman, K., Tavtigian, S., Liu, Q., Cochran, C., Bennett, L.M., Ding, W. and et al. (1994) Science, 266, 66-71

[9] Easton, D.F., Pooley, K.A., Dunning, A.M., Pharoah, P.D., Thompson, D., Ballinger, D.G., Struewing, J.P., Morrison, J., Field, H., Luben, R., Wareham, N., Ahmed, S., Healey, C.S., Bowman, R., Meyer, K.B., Haiman, C.A., Kolonel, L.K., Henderson, B.E., Le Marchand, L., Brennan, P., Sangrajrang, S., Gaborieau, V., Odefrey, F., Shen, C.Y., Wu, P.E., Wang, H.C., Eccles, D., Evans, D.G., Peto, J., Fletcher, O., Johnson, N., Seal, S., Stratton, M.R., Rahman, N., Chenevix-Trench, G., Bojesen, S.E., Nordestgaard, B.G., Axelsson, C.K., Garcia-Closas, M., Brinton, L., Chanock, S., Lissowska, J., Peplonska, B., Nevanlinna, H., Fagerholm, R., Eerola, H., Kang, D., Yoo, K.Y., Noh, D.Y., Ahn, S.H., Hunter, D.J., Hankinson, S.E., Cox, D.G., Hall, P., Wedren, S., Liu, J., Low, Y.L., Bogdanova, N., Schurmann, P., Dork, T., Tollenaar, R.A., Jacobi, C.E., Devilee, P., Klijn, J.G., Sigurdson, A.J., Doody, M.M., Alexander, B.H., Zhang, J., Cox, A., Brock, I.W., MacPherson, G., Reed, M.W., Couch, F.J., Goode, E.L., Olson, J.E., Meijers-Heijboer, H., 
van den Ouweland, A., Uitterlinden, A., Rivadeneira, F., Milne, R.L., Ribas, G., GonzalezNeira, A., Benitez, J., Hopper, J.L., McCredie, M., Southey, M., Giles, G.G., Schroen, C., Justenhoven, C., Brauch, H., Hamann, U., Ko, Y.D., Spurdle, A.B., Beesley, J., Chen, X., Mannermaa, A., Kosma, V.M., Kataja, V., Hartikainen, J., Day, N.E., Cox, D.R. and Ponder, B.A. (2007) Nature, 447, 1087-1093

[10] Huijts, P.E., Vreeswijk, M.P., Kroeze-Jansema, K.H., Jacobi, C.E., Seynaeve, C., Krol-Warmerdam, E.M., Wijers-Koster, P.M., Blom, J.C., Pooley, K.A., Klijn, J.G., Tollenaar, R.A., Devilee, P. and van Asperen, C.J. (2007) Breast Cancer Res, 9, R78

[11] Willems, P.J. (2007) Clin Genet, 72, 493-496

[12] Easton, D.F., Ford, D. and Bishop, D.T. (1995) Am J Hum Genet, 56, 265-271

[13] Ford, D., Easton, D.F., Stratton, M., Narod, S., Goldgar, D., Devilee, P., Bishop, D.T., Weber, B., Lenoir, G., Chang-Claude, J., Sobol, H., Teare, M.D., Struewing, J., Arason, A., Scherneck, S., Peto, J., Rebbeck, T.R., Tonin, P., Neuhausen, S., Barkardottir, R., Eyfjord, J., Lynch, H., Ponder, B.A., Gayther, S.A., Zelada-Hedman, M. and et al. (1998) Am J Hum Genet, 62, 676-689

[14] Marshall, M. and Solomon, S. (2007) Plast Surg Nurs, 27, 124-127

[15] Struewing, J.P., Hartge, P., Wacholder, S., Baker, S.M., Berlin, M., McAdams, M., Timmerman, M.M., Brody, L.C. and Tucker, M.A. (1997) N Engl J Med, 336, 1401-1408

[16] Brodie, S.G. and Deng, C.X. (2001) Trends Genet, 17, S18-22

[17] Brodie, S.G., Xu, X., Qiao, W., Li, W.M., Cao, L. and Deng, C.X. (2001) Oncogene, 20, 7514-7523.

[18] Samani, A.A., Yakar, S., LeRoith, D. and Brodt, P. (2007) Endocr Rev, 28, 20-47

[19] Riedemann, J. and Macaulay, V.M. (2006) Endocr Relat Cancer, 13 Suppl 1, S33-43

[20] Daughaday, W.H. (1989) Perspect Biol Med, 32, 194-211 
[21] Daughaday, W.H., Hall, K., Salmon, W.D., Jr., Van den Brande, J.L. and Van Wyk, J.J. (1987) J Clin Endocrinol Metab, 65, 1075-1076

[22] Vajdos, F.F., Ultsch, M., Schaffer, M.L., Deshayes, K.D., Liu, J., Skelton, N.J. and de Vos, A.M. (2001) Biochemistry, 40, 11022-11029

[23] Terasawa, H., Kohda, D., Hatanaka, H., Nagata, K., Higashihashi, N., Fujiwara, H., Sakano, K. and Inagaki, F. (1994) Embo J, 13, 5590-5597

[24] DeChiara, T.M., Efstratiadis, A. and Robertson, E.J. (1990) Nature, 345, 78-80

[25] Liu, J.P., Baker, J., Perkins, A.S., Robertson, E.J. and Efstratiadis, A. (1993) Cell, 75, $59-72$

[26] Walenkamp, M.J., Karperien, M., Pereira, A.M., Hilhorst-Hofstee, Y., van Doorn, J., Chen, J.W., Mohan, S., Denley, A., Forbes, B., van Duyvenvoorde, H.A., van Thiel, S.W., Sluimers, C.A., Bax, J.J., de Laat, J.A., Breuning, M.B., Romijn, J.A. and Wit, J.M. (2005) J Clin Endocrinol Metab, 90, 2855-2864

[27] Sara, V.R. and Hall, K. (1990) Physiol Rev, 70, 591-614

[28] Allan, G.J., Flint, D.J. and Patel, K. (2001) Reproduction, 122, 31-39

[29] Nakae, J., Kido, Y. and Accili, D. (2001) Endocr Rev, 22, 818-835

[30] Rubin, J.B., Shia, M.A. and Pilch, P.F. (1983) Nature, 305, 438-440

[31] Ullrich, A., Gray, A., Tam, A.W., Yang-Feng, T., Tsubokawa, M., Collins, C., Henzel, W., Le Bon, T., Kathuria, S., Chen, E. and et al. (1986) Embo J, 5, 2503-2512 [32] Morgan, D.O., Edman, J.C., Standring, D.N., Fried, V.A., Smith, M.C., Roth, R.A. and Rutter, W.J. (1987) Nature, 329, 301-307

[33] Kornfeld, S. (1992) Annu Rev Biochem, 61, 307-330

[34] Soos, M.A. and Siddle, K. (1989) Biochem J, 263, 553-563

[35] Treadway, J.L., Morrison, B.D., Goldfine, I.D. and Pessin, J.E. (1989) J Biol Chem, 264, 21450-21453 
[36] Denley, A., Cosgrove, L.J., Booker, G.W., Wallace, J.C. and Forbes, B.E. (2005) Cytokine Growth Factor Rev, 16, 421-439

[37] Laviola, L., Natalicchio, A. and Giorgino, F. (2007) Curr Pharm Des, 13, 663-669

[38] D'Ercole, A.J. (1996) Endocrinol Metab Clin North Am, 25, 573-590

[39] Frystyk, J. (2004) Growth Horm IGF Res, 14, 337-375

[40] Jones, J.I. and Clemmons, D.R. (1995) Endocr Rev, 16, 3-34

[41] Laursen, L.S., Kjaer-Sorensen, K., Andersen, M.H. and Oxvig, C. (2007) Mol Endocrinol, 21, 1246-1257

[42] Moralez, A.M., Maile, L.A., Clarke, J., Busby, W.H., Jr. and Clemmons, D.R. (2005) J Cell Physiol, 203, 328-334

[43] Mishra, S. and Murphy, L.J. (2003) Endocrinology, 144, 4042-4050

[44] Fu, P., Thompson, J.A. and Bach, L.A. (2007) J Biol Chem, 282, 22298-22306

[45] Kato, H., Faria, T.N., Stannard, B., Roberts, C.T., Jr. and LeRoith, D. (1994) Mol Endocrinol, 8, 40-50

[46] Hongo, A., D'Ambrosio, C., Miura, M., Morrione, A. and Baserga, R. (1996) Oncogene, 12, 1231-1238

[47] Hermanto, U., Zong, C.S. and Wang, L.H. (2000) Cell Growth Differ, 11, 655-664

[48] Grey, A., Chen, Q., Xu, X., Callon, K. and Cornish, J. (2003) Endocrinology, 144, 4886-4893

[49] Rommel, C., Clarke, B.A., Zimmermann, S., Nunez, L., Rossman, R., Reid, K., Moelling, K., Yancopoulos, G.D. and Glass, D.J. (1999) Science, 286, 1738-1741

[50] Zong, C.S., Zeng, L., Jiang, Y., Sadowski, H.B. and Wang, L.H. (1998) J Biol Chem, $273,28065-28072$

[51] Beitner-Johnson, D., Blakesley, V.A., Shen-Orr, Z., Jimenez, M., Stannard, B., Wang, L.M., Pierce, J. and LeRoith, D. (1996) J Biol Chem, 271, 9287-9290 
[52] Dey, B.R., Frick, K., Lopaczynski, W., Nissley, S.P. and Furlanetto, R.W. (1996) Mol Endocrinol, 10, 631-641

[53] Seely, B.L., Reichart, D.R., Staubs, P.A., Jhun, B.H., Hsu, D., Maegawa, H., Milarski, K.L., Saltiel, A.R. and Olefsky, J.M. (1995) J Biol Chem, 270, 19151-19157

[54] Buckley, D.A., Cheng, A., Kiely, P.A., Tremblay, M.L. and O'Connor, R. (2002) Mol Cell Biol, 22, 1998-2010

[55] Akekawatchai, C., Holland, J.D., Kochetkova, M., Wallace, J.C. and McColl, S.R. (2005) J Biol Chem, 280, 39701-39708

[56] Dufourny, B., Alblas, J., van Teeffelen, H.A., van Schaik, F.M., van der Burg, B., Steenbergh, P.H. and Sussenbach, J.S. (1997) J Biol Chem, 272, 31163-31171

[57] Kalluri, H.S., Vemuganti, R. and Dempsey, R.J. (2007) Eur J Neurosci, 25, 10411048

[58] Yang, W., Zhang, Y., Li, Y., Wu, Z. and Zhu, D. (2007) J Biol Chem, 282, 3799-3808

[59] Brisken, C., Ayyannan, A., Nguyen, C., Heineman, A., Reinhardt, F., Tan, J., Dey, S.K., Dotto, G.P. and Weinberg, R.A. (2002) Dev Cell, 3, 877-887

[60] Dufourny, B., van Teeffelen, H.A., Hamelers, I.H., Sussenbach, J.S. and Steenbergh, P.H. (2000) J Endocrinol, 166, 329-338

[61] Muise-Helmericks, R.C., Grimes, H.L., Bellacosa, A., Malstrom, S.E., Tsichlis, P.N. and Rosen, N. (1998) J Biol Chem, 273, 29864-29872

[62] Diehl, J.A., Cheng, M., Roussel, M.F. and Sherr, C.J. (1998) Genes Dev, 12, 34993511

[63] Hamelers, I.H., van Schaik, R.F., Sipkema, J., Sussenbach, J.S. and Steenbergh, P.H. (2002) J Biol Chem, 277, 47645-47652

[64] Dupont, J., Pierre, A., Froment, P. and Moreau, C. (2003) Horm Metab Res, 35, 740750 
[65] Medema, R.H., Kops, G.J., Bos, J.L. and Burgering, B.M. (2000) Nature, 404, 782787

[66] Fujita, N., Sato, S., Katayama, K. and Tsuruo, T. (2002) J Biol Chem, 277, 2870628713

[67] Adesanya, O.O., Zhou, J., Samathanam, C., Powell-Braxton, L. and Bondy, C.A. (1999) Proc Natl Acad Sci U S A, 96, 3287-3291

[68] Stromberg, T., Ekman, S., Girnita, L., Dimberg, L.Y., Larsson, O., Axelson, M., Lennartsson, J., Hellman, U., Carlson, K., Osterborg, A., Vanderkerken, K., Nilsson, K. and Jernberg-Wiklund, H. (2006) Blood, 107, 669-678

[69] Varela-Nieto, I., Hartl, M., Gorospe, I. and Leon, Y. (2007) Curr Pharm Des, 13, $687-703$

[70] Zheng, W.H., Kar, S. and Quirion, R. (2002) Mol Pharmacol, 62, 225-233

[71] Tu, W., Cheung, P.T. and Lau, Y.L. (2000) J Immunol, 165, 1331-1336

[72] Feldser, D., Agani, F., Iyer, N.V., Pak, B., Ferreira, G. and Semenza, G.L. (1999) Cancer Res, 59, 3915-3918

[73] Fukuda, R., Hirota, K., Fan, F., Jung, Y.D., Ellis, L.M. and Semenza, G.L. (2002) J Biol Chem, 277, 38205-38211

[74] Zelzer, E., Levy, Y., Kahana, C., Shilo, B.Z., Rubinstein, M. and Cohen, B. (1998) Embo J, 17, 5085-5094

[75] Carroll, V.A. and Ashcroft, M. (2006) Cancer Res, 66, 6264-6270

[76] Shigematsu, S., Yamauchi, K., Nakajima, K., Iijima, S., Aizawa, T. and Hashizume, K. (1999) Endocr J, 46 Suppl, S59-62

[77] Bjorndahl, M., Cao, R., Nissen, L.J., Clasper, S., Johnson, L.A., Xue, Y., Zhou, Z., Jackson, D., Hansen, A.J. and Cao, Y. (2005) Proc Natl Acad Sci U S A, 102, 15593-15598

[78] Guvakova, M.A., Adams, J.C. and Boettiger, D. (2002) J Cell Sci, 115, 4149-4165 
[79] Zhang, D., Bar-Eli, M., Meloche, S. and Brodt, P. (2004) J Biol Chem, 279, 1968319690

[80] Zhang, D. and Brodt, P. (2003) Oncogene, 22, 974-982

[81] Mira, E., Manes, S., Lacalle, R.A., Marquez, G. and Martinez, A.C. (1999) Endocrinology, 140, 1657-1664

[82] Dunn, S.E., Torres, J.V., Oh, J.S., Cykert, D.M. and Barrett, J.C. (2001) Cancer Res, 61, 1367-1374

[83] Ma, Z., Dong, A., Kong, M. and Qian, J. (2007) Cell Mol Biol Lett, 12, 556-572

[84] van Golen, C.M., Schwab, T.S., Kim, B., Soules, M.E., Su Oh, S., Fung, K., van Golen, K.L. and Feldman, E.L. (2006) Cancer Res, 66, 6570-6578

[85] Kaleko, M., Rutter, W.J. and Miller, A.D. (1990) Mol Cell Biol, 10, 464-473

[86] Sell, C., Rubini, M., Rubin, R., Liu, J.P., Efstratiadis, A. and Baserga, R. (1993) Proc Natl Acad Sci U S A, 90, 11217-11221

[87] Sell, C., Dumenil, G., Deveaud, C., Miura, M., Coppola, D., DeAngelis, T., Rubin, R., Efstratiadis, A. and Baserga, R. (1994) Mol Cell Biol, 14, 3604-3612

[88] Chan, J.M., Stampfer, M.J., Giovannucci, E., Gann, P.H., Ma, J., Wilkinson, P., Hennekens, C.H. and Pollak, M. (1998) Science, 279, 563-566

[89] Mantzoros, C.S., Tzonou, A., Signorello, L.B., Stampfer, M., Trichopoulos, D. and Adami, H.O. (1997) Br J Cancer, 76, 1115-1118

[90] Stuver, S.O., Kuper, H., Tzonou, A., Lagiou, P., Spanos, E., Hsieh, C.C., Mantzoros, C. and Trichopoulos, D. (2000) Int J Cancer, 87, 118-121

[91] Pezzino, V., Papa, V., Milazzo, G., Gliozzo, B., Russo, P. and Scalia, P.L. (1996) Ann N Y Acad Sci, 784, 189-201

[92] Ueda, S., Tsuda, H., Sato, K., Takeuchi, H., Shigekawa, T., Matsubara, O., Hiraide, H. and Mochizuki, H. (2006) Cancer Sci, 97, 597-604 
[93] Shimizu, C., Hasegawa, T., Tani, Y., Takahashi, F., Takeuchi, M., Watanabe, T., Ando, M., Katsumata, N. and Fujiwara, Y. (2004) Hum Pathol, 35, 1537-1542

[94] Chong, Y.M., Williams, S.L., Elkak, A., Sharma, A.K. and Mokbel, K. (2006) Anticancer Res, 26, 167-173

[95] Knowlden, J.M., Hutcheson, I.R., Barrow, D., Gee, J.M. and Nicholson, R.I. (2005) Endocrinology, 146, 4609-4618

[96] Hadsell, D.L., Murphy, K.L., Bonnette, S.G., Reece, N., Laucirica, R. and Rosen, J.M. (2000) Oncogene, 19, 889-898

[97] Bates, P., Fisher, R., Ward, A., Richardson, L., Hill, D.J. and Graham, C.F. (1995) Br J Cancer, 72, 1189-1193

[98] Yee, D., Paik, S., Lebovic, G.S., Marcus, R.R., Favoni, R.E., Cullen, K.J., Lippman, M.E. and Rosen, N. (1989) Mol Endocrinol, 3, 509-517

[99] Paik, S. (1992) Breast Cancer Res Treat, 22, 31-38

[100] Gebauer, G., Jager, W. and Lang, N. (1998) Anticancer Res, 18, 1191-1195

[101] Allen, N.E., Roddam, A.W., Allen, D.S., Fentiman, I.S., Dos Santos Silva, I., Peto, J., Holly, J.M. and Key, T.J. (2005) Br J Cancer, 92, 1283-1287

[102] Hankinson, S.E., Willett, W.C., Colditz, G.A., Hunter, D.J., Michaud, D.S., Deroo, B., Rosner, B., Speizer, F.E. and Pollak, M. (1998) Lancet, 351, 1393-1396

[103] Toniolo, P., Bruning, P.F., Akhmedkhanov, A., Bonfrer, J.M., Koenig, K.L., Lukanova, A., Shore, R.E. and Zeleniuch-Jacquotte, A. (2000) Int J Cancer, 88, 828-832 [104] Wagner, K., Hemminki, K., Israelsson, E., Grzybowska, E., Klaes, R., Chen, B., Butkiewicz, D., Pamula, J., Pekala, W. and Forsti, A. (2005) Endocr Relat Cancer, 12, 917928 
[105] Cleveland, R.J., Gammon, M.D., Edmiston, S.N., Teitelbaum, S.L., Britton, J.A., Terry, M.B., Eng, S.M., Neugut, A.I., Santella, R.M. and Conway, K. (2006) Carcinogenesis, 27, 758-765

[106] Jernstrom, H., Sandberg, T., Bageman, E., Borg, A. and Olsson, H. (2006) Int J Gynecol Cancer, 16 Suppl 2, 497

[107] Jernstrom, H., Sandberg, T., Bageman, E., Borg, A. and Olsson, H. (2005) Br J Cancer, 92, 857-866

[108] Figer, A., Karasik, Y.P., Baruch, R.G., Chetrit, A., Papa, M.Z., Sade, R.B., Rizel, S. and Friedman, E. (2002) Isr Med Assoc J, 4, 759-762

[109] Yang, X.F., Beamer, W.G., Huynh, H. and Pollak, M. (1996) Cancer Res, 56, 15091511

[110] Pollak, M., Blouin, M.J., Zhang, J.C. and Kopchick, J.J. (2001) Br J Cancer, 85, 428430

[111] Wu, Y., Cui, K., Miyoshi, K., Hennighausen, L., Green, J.E., Setser, J., LeRoith, D. and Yakar, S. (2003) Cancer Res, 63, 4384-4388

[112] Carboni, J.M., Lee, A.V., Hadsell, D.L., Rowley, B.R., Lee, F.Y., Bol, D.K., Camuso, A.E., Gottardis, M., Greer, A.F., Ho, C.P., Hurlburt, W., Li, A., Saulnier, M., Velaparthi, U., Wang, C., Wen, M.L., Westhouse, R.A., Wittman, M., Zimmermann, K., Rupnow, B.A. and Wong, T.W. (2005) Cancer Res, 65, 3781-3787

[113] Jackson, J.G., Zhang, X., Yoneda, T. and Yee, D. (2001) Oncogene, 20, 7318-7325

[114] Sachdev, D., Hartell, J.S., Lee, A.V., Zhang, X. and Yee, D. (2004) J Biol Chem, 279, $5017-5024$

[115] Deng, C.X. (2006) Nucleic Acids Res, 34, 1416-1426

[116] Lane, T.F., Deng, C., Elson, A., Lyu, M.S., Kozak, C.A. and Leder, P. (1995) Genes Dev, 9, 2712-2722 
[117] ElShamy, W.M. and Livingston, D.M. (2004) Nat Cell Biol, 6, 954-967. Epub 2004 Sep 2026.

[118] Thakur, S., Zhang, H.B., Peng, Y., Le, H., Carroll, B., Ward, T., Yao, J., Farid, L.M., Couch, F.J., Wilson, R.B. and Weber, B.L. (1997) Mol Cell Biol, 17, 444-452

[119] Wilson, C.A., Payton, M.N., Elliott, G.S., Buaas, F.W., Cajulis, E.E., Grosshans, D., Ramos, L., Reese, D.M., Slamon, D.J. and Calzone, F.J. (1997) Oncogene, 14, 1-16

[120] Xu, X., Weaver, Z., Linke, S.P., Li, C., Gotay, J., Wang, X.W., Harris, C.C., Ried, T. and Deng, C.X. (1999) Mol Cell, 3, 389-395

[121] Deng, C.X. and Brodie, S.G. (2000) Bioessays, 22, 728-737

[122] Voskuil, D.W., Bosma, A., Vrieling, A., Rookus, M.A. and van 't Veer, L.J. (2004) Breast Cancer Res Treat, 84, 225-233

[123] Werner, H., Re, G.G., Drummond, I.A., Sukhatme, V.P., Rauscher, F.J., 3rd, Sens, D.A., Garvin, A.J., LeRoith, D. and Roberts, C.T., Jr. (1993) Proc Natl Acad Sci U S A, 90, $5828-5832$

[124] Werner, H., Bach, M.A., Stannard, B., Roberts, C.T., Jr. and LeRoith, D. (1992) Mol Endocrinol, 6, 1545-1558

[125] Werner, H., Shalita-Chesner, M., Abramovitch, S., Idelman, G., Shaharabani-Gargir, L. and Glaser, T. (2000) Mol Genet Metab, 71, 315-320

[126] Maor, S.B., Abramovitch, S., Erdos, M.R., Brody, L.C. and Werner, H. (2000) Mol Genet Metab, 69, 130-136

[127] Abramovitch, S. and Werner, H. (2003) Horm Metab Res, 35, 758-762

[128] Maor, S., Yosepovich, A., Papa, M.Z., Yarden, R.I., Mayer, D., Friedman, E. and Werner, H. (2007) Cancer Lett, 257, 236-243

[129] Sarfstein, R., Maor, S., Reizner, N., Abramovitch, S. and Werner, H. (2006) Mol Cell Endocrinol, 252, 241-246 
[130] Xu, X., Qiao, W., Linke, S.P., Cao, L., Li, W.M., Furth, P.A., Harris, C.C. and Deng, C.X. (2001) Nat Genet, 28, 266-271.

[131] Cao, L., Xu, X., Cao, L.L., Wang, R.H., Coumoul, X., Kim, S.S. and Deng, C.X. (2007) Carcinogenesis, 28, 1401-1407

[132] Cao, L., Li, W., Kim, S., Brodie, S.G. and Deng, C.X. (2003) Genes Dev, 17, 201-213

[133] Cao, L., Kim, S., Xiao, C., Wang, R.H., Coumoul, X., Wang, X., Li, W.M., Xu, X.L., De Soto, J.A., Takai, H., Mai, S., Elledge, S.J., Motoyama, N. and Deng, C.X. (2006) Embo $J, 25,2167-2177$

[134] Bachelier, R., Xu, X., Wang, X., Li, W., Naramura, M., Gu, H. and Deng, C.X. (2003) Oncogene, 22, 528-537

[135] Bachelier, R., Xu, X., Li, C., Qiao, W., Furth, P.A., Lubet, R.A. and Deng, C.X. (2005) Oncol Rep, 14, 1117-1120

[136] Shukla, V., Coumoul, X., Cao, L., Wang, R., Xiao, C., Xu, X., Ando, S., Yakar, S., LeRoith, D. and Deng, D. (2006) Cancer Research, 66, 7151-7157

[137] Renehan, A.G., Frystyk, J. and Flyvbjerg, A. (2006) Trends Endocrinol Metab, 17, $328-336$

[138] Dunn, S.E., Kari, F.W., French, J., Leininger, J.R., Travlos, G., Wilson, R. and Barrett, J.C. (1997) Cancer Res, 57, 4667-4672

[139] Hursting, S.D., Switzer, B.R., French, J.E. and Kari, F.W. (1993) Cancer Res, 53, $2750-2757$

[140] Chatzistamou, I., Schally, A.V., Varga, J.L., Groot, K., Armatis, P., Busto, R. and Halmos, G. (2001) J Clin Endocrinol Metab, 86, 2144-2152

[141] Divisova, J., Kuiatse, I., Lazard, Z., Weiss, H., Vreeland, F., Hadsell, D.L., Schiff, R., Osborne, C.K. and Lee, A.V. (2006) Breast Cancer Res Treat, 98, 315-327 
[142] Friend, K.E., Khandwala, H.M., Flyvbjerg, A., Hill, H., Li, J. and McCutcheon, I.E. (2001) Growth Horm IGF Res, 11, 84-91

[143] Zhang, X. and Yee, D. (2002) Cancer Res, 62, 4369-4375

[144] Aberg, N.D., Brywe, K.G. and Isgaard, J. (2006) ScientificWorldJournal, 6, 53-80

[145] Adamo, M.L. and Farrar, R.P. (2006) Ageing Res Rev, 5, 310-331

[146] Arteaga, C.L. and Osborne, C.K. (1989) Cancer Res, 49, 6237-6241

[147] Burtrum, D., Zhu, Z., Lu, D., Anderson, D.M., Prewett, M., Pereira, D.S., Bassi, R., Abdullah, R., Hooper, A.T., Koo, H., Jimenez, X., Johnson, D., Apblett, R., Kussie, P., Bohlen, P., Witte, L., Hicklin, D.J. and Ludwig, D.L. (2003) Cancer Res, 63, 8912-8921

[148] Cohen, B.D., Baker, D.A., Soderstrom, C., Tkalcevic, G., Rossi, A.M., Miller, P.E., Tengowski, M.W., Wang, F., Gualberto, A., Beebe, J.S. and Moyer, J.D. (2005) Clin Cancer Res, 11, 2063-2073

[149] Kull, F.C., Jr., Jacobs, S., Su, Y.F., Svoboda, M.E., Van Wyk, J.J. and Cuatrecasas, P. (1983) J Biol Chem, 258, 6561-6566

[150] Li, S.L., Liang, S.J., Guo, N., Wu, A.M. and Fujita-Yamaguchi, Y. (2000) Cancer Immunol Immunother, 49, 243-252

[151] Maloney, E.K., McLaughlin, J.L., Dagdigian, N.E., Garrett, L.M., Connors, K.M., Zhou, X.M., Blattler, W.A., Chittenden, T. and Singh, R. (2003) Cancer Res, 63, 5073-5083

[152] Sachdev, D., Li, S.L., Hartell, J.S., Fujita-Yamaguchi, Y., Miller, J.S. and Yee, D. (2003) Cancer Res, 63, 627-635

[153] Ye, J.J., Liang, S.J., Guo, N., Li, S.L., Wu, A.M., Giannini, S., Sachdev, D., Yee, D., Brunner, N., Ikle, D. and Fujita-Yamaguchi, Y. (2003) Horm Metab Res, 35, 836-842

[154] Lu, D., Zhang, H., Koo, H., Tonra, J., Balderes, P., Prewett, M., Corcoran, E., Mangalampalli, V., Bassi, R., Anselma, D., Patel, D., Kang, X., Ludwig, D.L., Hicklin, D.J., Bohlen, P., Witte, L. and Zhu, Z. (2005) J Biol Chem, 280, 19665-19672 
[155] Lu, D., Zhang, H., Ludwig, D., Persaud, A., Jimenez, X., Burtrum, D., Balderes, P., Liu, M., Bohlen, P., Witte, L. and Zhu, Z. (2004) J Biol Chem, 279, 2856-2865

[156] Clemmons, D.R. (2007) Nat Rev Drug Discov, 6, 821-833

[157] Jackson-Booth, P.G., Terry, C., Lackey, B., Lopaczynska, M. and Nissley, P. (2003) Horm Metab Res, 35, 850-856

[158] Bohula, E.A., Playford, M.P. and Macaulay, V.M. (2003) Anticancer Drugs, 14, 669682

[159] Wang, Y., Hailey, J., Williams, D., Wang, Y., Lipari, P., Malkowski, M., Wang, X., Xie, L., Li, G., Saha, D., Ling, W.L., Cannon-Carlson, S., Greenberg, R., Ramos, R.A., Shields, R., Presta, L., Brams, P., Bishop, W.R. and Pachter, J.A. (2005) Mol Cancer Ther, 4, $1214-1221$

[160] Feng, Y., Zhu, Z., Xiao, X., Choudhry, V., Barrett, J.C. and Dimitrov, D.S. (2006) Mol Cancer Ther, 5, 114-120

[161] Goya, M., Miyamoto, S., Nagai, K., Ohki, Y., Nakamura, K., Shitara, K., Maeda, H., Sangai, T., Kodama, K., Endoh, Y., Ishii, G., Hasebe, T., Yonou, H., Hatano, T., Ogawa, Y. and Ochiai, A. (2004) Cancer Res, 64, 6252-6258

[162] Gable, K.L., Maddux, B.A., Penaranda, C., Zavodovskaya, M., Campbell, M.J., Lobo, M., Robinson, L., Schow, S., Kerner, J.A., Goldfine, I.D. and Youngren, J.F. (2006) Mol Cancer Ther, 5, 1079-1086

[163] Girnita, A., All-Ericsson, C., Economou, M.A., Astrom, K., Axelson, M., Seregard, S., Larsson, O. and Girnita, L. (2006) Clin Cancer Res, 12, 1383-1391

[164] Parrizas, M., Gazit, A., Levitzki, A., Wertheimer, E. and LeRoith, D. (1997) Endocrinology, 138, 1427-1433

[165] Wen, B., Deutsch, E., Marangoni, E., Frascona, V., Maggiorella, L., Abdulkarim, B., Chavaudra, N. and Bourhis, J. (2001) Br J Cancer, 85, 2017-2021 
[166] Haluska, P., Carboni, J.M., Loegering, D.A., Lee, F.Y., Wittman, M., Saulnier, M.G., Frennesson, D.B., Kalli, K.R., Conover, C.A., Attar, R.M., Kaufmann, S.H., Gottardis, M. and Erlichman, C. (2006) Cancer Res, 66, 362-371

[167] Garcia-Echeverria, C., Pearson, M.A., Marti, A., Meyer, T., Mestan, J., Zimmermann, J., Gao, J., Brueggen, J., Capraro, H.G., Cozens, R., Evans, D.B., Fabbro, D., Furet, P., Porta, D.G., Liebetanz, J., Martiny-Baron, G., Ruetz, S. and Hofmann, F. (2004) Cancer Cell, 5, 231-239

[168] Mitsiades, C.S., Mitsiades, N.S., McMullan, C.J., Poulaki, V., Shringarpure, R., Akiyama, M., Hideshima, T., Chauhan, D., Joseph, M., Libermann, T.A., Garcia-Echeverria, C., Pearson, M.A., Hofmann, F., Anderson, K.C. and Kung, A.L. (2004) Cancer Cell, 5, 221230

[169] Girnita, A., Girnita, L., del Prete, F., Bartolazzi, A., Larsson, O. and Axelson, M. (2004) Cancer Res, 64, 236-242

[170] Vasilcanu, D., Girnita, A., Girnita, L., Vasilcanu, R., Axelson, M. and Larsson, O. (2004) Oncogene, 23, 7854-7862

[171] Min, Y., Adachi, Y., Yamamoto, H., Ito, H., Itoh, F., Lee, C.T., Nadaf, S., Carbone, D.P. and Imai, K. (2003) Cancer Res, 63, 6432-6441

[172] Surmacz, E. (2003) Oncogene, 22, 6589-6597

[173] Kohno, M. and Pouyssegur, J. (2003) Prog Cell Cycle Res, 5, 219-224

[174] Catrina, S.B., Botusan, I.R., Rantanen, A., Catrina, A.I., Pyakurel, P., Savu, O., Axelson, M., Biberfeld, P., Poellinger, L. and Brismar, K. (2006) Clin Cancer Res, 12, 45064514

[175] Catrina, S.B., Lewitt, M., Massambu, C., Dricu, A., Grunler, J., Axelson, M., Biberfeld, P. and Brismar, K. (2005) Br J Cancer, 92, 1467-1474

[176] Brahimi-Horn, M.C. and Pouyssegur, J. (2007) FEBS Lett, 581, 3582-3591 
[177] Semenza, G.L. (2007) Science, 318, 62-64

[178] Stawowy, P., Kallisch, H., Kilimnik, A., Margeta, C., Seidah, N.G., Chretien, M., Fleck, E. and Graf, K. (2004) Biochem Biophys Res Commun, 321, 531-538

[179] Zhang, D., Samani, A.A. and Brodt, P. (2003) Horm Metab Res, 35, 802-808

[180] Nuti, E., Tuccinardi, T. and Rossello, A. (2007) Curr Pharm Des, 13, 2087-2100

[181] Abramovitch, S., Glaser, T., Ouchi, T. and Werner, H. (2003) FEBS Lett, 541, 149154

[182] Werner, H., Karnieli, E., Rauscher, F.J. and LeRoith, D. (1996) Proc Natl Acad Sci U $S A, 93,8318-8323$

[183] Pauwels, E.K. and Erba, P. (2007) Drug News Perspect, 20, 213-220

[184] Torchilin, V.P. (2007) Aaps J,9, E128-147

[185] Shukla, V., Coumoul, X. and Deng, C.X. (2007) Int J Biol Sci, 3, 91-99

[186] Shukla, V., Coumoul, X., Wang, R.H., Kim, H.S. and Deng, C.X. (2007) Nat Genet, 39, $1145-1150$ 